\title{
マスク修正装 置*
}

\section{辰 巳 龍 司**}

Key words : laser, VLSI, Nd: YAG laser, mask repair, opaque defect, transmissive defect, laser CVD

LSI, 超 LSI の微細化, 高集積密度化は, メモリーの 大容量化に伴い急速に進展している. 超 LSI 開発プロ シェクトの一環として進められた，フォトマスク（以 後マスクと略す）の自動検査とレーザによる修正技術 は, 現在, マスク製造の標準工程として定着し, マス クの品質向上はもちろん，半導体デバイスの歩どまり と信頼性向上に大きく寄与している。

本稿では, マスク欠陷修正の意味, レーザによるマ スク修正技術, 装置構成と性能, 今後の修正技術の動 向等について述べる.

\section{1. マスク欠陥修正の意味}

\section{1 マスク欠陥の種類}

IC 回路の微細化に伴いマスクの品質・精度に対する 要求が厳しくなっており, マスクの欠陷検査と修正の 重要性がますます高くなっている。

マスクの外観欠陥の種類を図 1 に示す。これらの欠 陷を大別すると，ピンホール・素子脱落のような欠損 欠陷之, 黒点・突起に代表される残留欠陥に分けられ る.これらの欠樎が発生する原因として, 空気中の塵 埃, エッチング液, 時間等エッチングプロセスにおけ る種々の問題, 取扱い時の機械的傷, 設計ミス等があ げられる。

これらに対処するため, 無鹿に近い製造環境やプロ セス管理の徹底，ハンドリングの自動化や CAD シス テム等により欠陷発生を防いできた。しかし，パター ンの微細化により，問題となる欠陷サイズがより小さ くなってきており，修正を必要とする欠陷の数は減っ ていないようである。

* 原稿受付 昭和 60 年 9 月 25 日

** 日本電気(株)（相模原市下九沢 1120）
現在，一般に採用されているレーザによるマスクリ ペアリングは，ガラス基板上の金属薄膜を除去加工寸 る技術であり,残留欠陷修正を目的としたものである。

\section{2 マスク修正の必要性}

マスクの欠陥が LSI や超 LSI 等デバイスの歩どま りと信頼性を低下させるであろうことは容易に理解さ れることであるが，IC製造プロセスの変化に伴い， 、 スク欠陷修正の意味・目的も若干变わってきている。

初期のプロセスでは, シリコンウェハへの光転写は コンタクト露光が主流であった。この段階では, マス

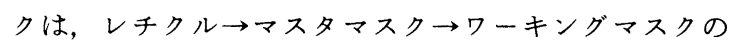
順で制作され，ワーキングマスクがデバイス製造に使 用される。したがって，ワーキングマスクに欠陥があ れば，直接デバイス歩どまりに反映することはいらま でもないが，レチクルに発生した欠陷は後工程のマス クに共通な欠陷となるため, この修正は極めて重要視 され優先された。しかし，各レベルのマスクの製造プ 口セスに拀いて, 欠陥発生の機会は同程度であるため,

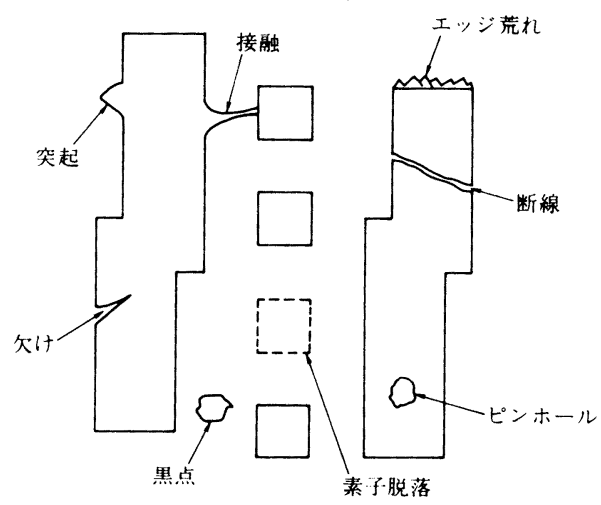

図 1 外観欠陷の種類 
すべてのマスクの欠陷修正が 必要となる。このことは，デ バイスの歩どまりを統計的に 扱った次の式からも明らかで ある。

集積回路製造においては, マスクの重ね合わせによりパ ターンを作るが，マスクの品 質と半導体デバイスの歩どま りとの間には, 次の関係式が

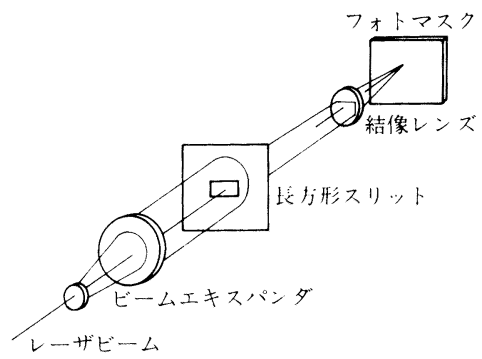

(a) 原埋闵

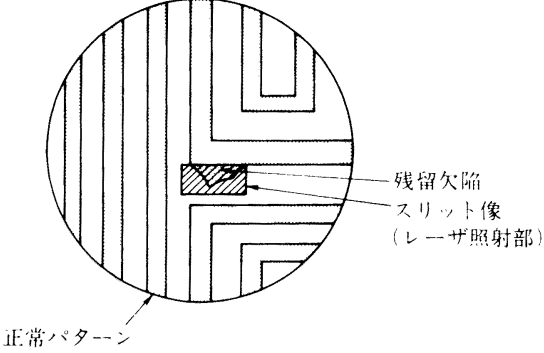

(b) フォトマスク搪大网

図 2 フォトマスク加工用レーザ制御の原理図

成り立つことが知られてい

る。

$$
Y=\{1 /(1+D A)\}^{N}
$$

ここで, $Y:$ デバイスの歩どまり $(\%), D ：$ マスクの 欠陷密度 (個 $\left./ \mathrm{cm}^{2}\right), A$ : チップ面積 $\left(\mathrm{cm}^{2}\right), N$ : デバ イス工程数.

この式は，デバイスのチップサイズが拡大した分だ け欠陥を减らさないとデバイス歩どまりが低下するこ とを意味している。

光転写がコンタクト方式からプロジェクション露光 に移行するにつれ使用されるマスクはマスタマスクの レベルが主体となる。

コンタクト露光やプロジェクション露光に拈いて は，上の式で表される式が成り立ち，またこの式は， 見方を変えると，ある程度のマスク欠陷があっても良 品デバイスを生産できることを意味している。

しかし，一層の微細化により採用されたステッパ露 光方式では事情が一変した. ステッパ露光では, 1 枚の レチクルによりシリコンウェハに縮小露光を繰り返す ため，欠陷のあるレチクルを使用すれば，全チップに 欠陥を生むことになる。すなわち，ステッパ露光では 無欠陥レチクルが必要となる。

上述したように, IC の露光技術の変化により, マス ク修正の意味・目的も変化してきたことがわかる.

\section{2.レーザによるマスク修正技術}

\section{1 マスク修正の原理}

レーザによる金属薄膜の加工は，レーザトリミング 技術で代表され，種々の央用化がなされている。マス ク修正も加工機能としてはトリミングに属するが，加 工形状の制御が重要なポイントであるといら点で多く のレーザ加工技術と異なっている.

レーザによる修正技術の特長は，1回のレーザの照 射による加工の「形」と「大きさ」を制御することに ある、マスク上に発生する欠陷の形状は一定したもの ではなく，また，その位置も高密度なところからそう

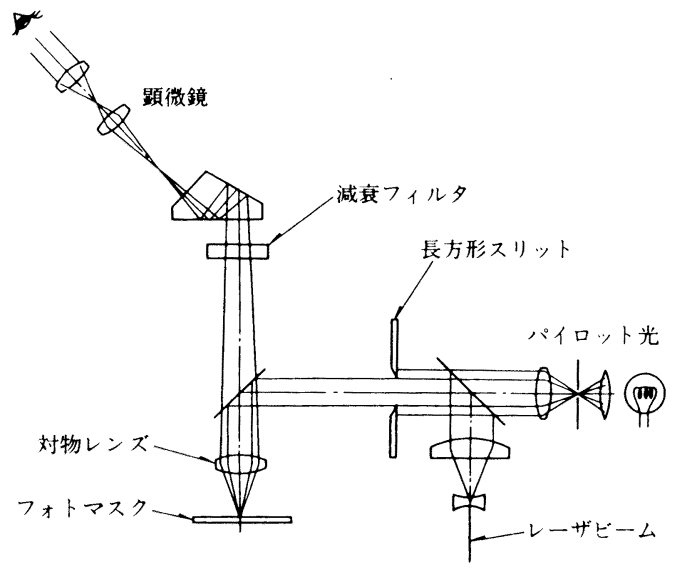

図 3 フォトマスク修正加工機用光学系の基本構成

でない部分と千差万別である。このように多様な欠陷 に対応するためのレーザ加工技術は，加工すべき欠陷 部だけに限定してレーザを照射し，その周辺には影響 を及ぼさないようにすることが大切である。したがっ て，レーザマスク修正においては，レーザが照射され る範囲（形と大ささ）を欠陷の形状に合わせて調整で きるレーザ制御技術と，レーザを照射する前に確認で きる観察手段が必須性能となる。

図 2 にマスク修正用レーザ制御の原理を示す。レー ザビームは，ビームエキスパンダで払大された後長方 形スリットを照らし，レーザビームによる長方形ス リットの開口部の像が結像レンズによりマスク上に作 られる。マスク上では図 2 (b) の拡大図のようにス リットの縮小像と欠陷部が重畳するように整合され る.

このようにして, 久陷部のみが除去され正常なパ ターンに影響を及ぼさない加工が可能となるが，実際 の場合には，レーザビームによって作られるスリット 像の位置と形および大きさをあらかじめ知り，その大 ささや形を調整して欠陥部と整合されることが必要で ある。図 3 はこのような諸要件を考慮した光学系の基 
本構成を示したすのである。この光学系では，レーザ ビームとパイロット光は光軸を共有するように調整さ れた後スりットを通過し，対物レンズによってマスク 面上にパイロット光およびレーザビームによるスリッ 卜像を作る。また，マスク面上の像を顕铰鏡により観 察することがでさる。このような光学系により，欠陥 の位置，大きさや形を知り，それに合わせてパイロッ ト光によるスリット像を調整でき，正確なレーザ加工 が行党ることになる。

\section{2 マスク修正の要件}

上述したような精度の高い加工を行らためのレーザ 光の制御の汪かに，マスク修正を実用とするために考 えておか、叔ばならい点について述べる。

第 1 に配慮しなければならないことは，作業者の眼 の保護である。マスク回路のような微細なパターンを 観察しその中から1〜2 $\mu \mathrm{m}$ の欠陥を確認するために は顕微鏡による観察が不可欠である。また，レーザ光 を照射する時にも顕微鏡から眼を離すことは作業能率 から考えてあり壳ない、したがって，眼の保護を確実 にするレーザの選択と光学系の構成を考光㸚ばならな い.

次に，レーザ照射時に基板ガラスに損傷がないこと も重要な条件である。レーザ光を十分制御して欠陷部 だけを正確に除去しても，その下の基板ガラスに傷が ついては無意味である。この点でレーザ光の波長およ び照射時間が重要な要素となる。

第 3 には，修正を効率よく行ら必要がある。先に述 ベたよらに，マスクに発生する欠陥は可能な限り修正 することがデバイスの歩どまりと信頼性向上にとって 極めて重要である。そのためには，欠陥を早く見つけ て修正作業の能率を高めることが必要であり，マスク 自動検查機の欠陥データをマスク修正機に入力する結 合インタフェースの拡充が必要である。

\section{3. 装置構成と性能}

\section{1 構 成}

以上のよらな諸要件を考慮して開発されたマスク修 正装置は, $\mathrm{Nd}$ ：YAG レーザの $1.06 \mu \mathrm{m}$ 光を用い, 最 小加工幅 (以後, 加工分解能々呼ぶ) が $2 \mu \mathrm{m}$ であり, マスク製造ラインへ普及した。超 LSI 回路の微細化々 ともに，サブミクロンの加工分解能の要求が強まり, 現在では， Nd：YAGレーザの第二高調波（波長 0.53 $\mu \mathrm{m} ）$ 光を用いた装置が実用されている。

図 4 は加工分解能 $0.7 \mu \mathrm{m}$ のレーザマスクリペア (SL 452 C)の外観写真である。この装置は, 各種のマ スク自動検査装置と,ケーブル, フロッピーディスク,

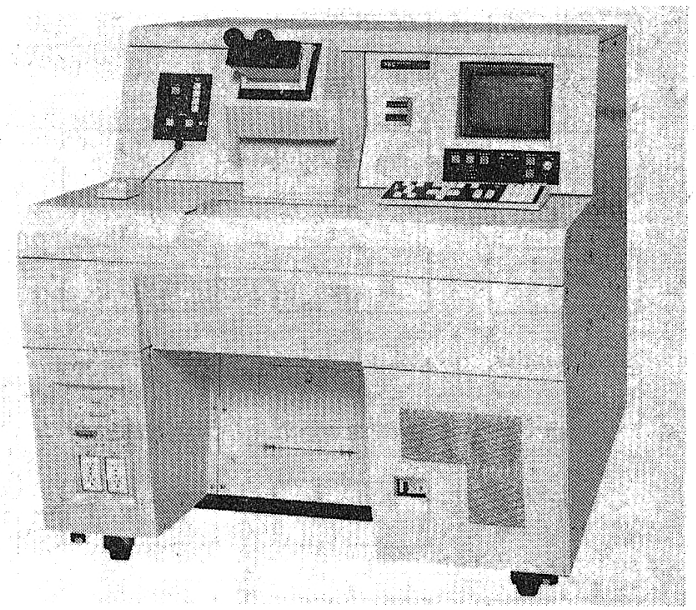

图 4 SL 452Cレーザマスクリペフ (NEC) の外観写真

磁気カード，カセットテープ等を介して結ぶことがで さる。京た，この装置は修正作業時の振動を防止する ため, 除振機構に十分な配慮をしている泀か, 光学系 各部の駆動機構をモータドライブとして作業者の接触 を防いでいる。図 5 はSL 452 Cレーザマスクリペア の構成を示すブロック図である。

これらの構成要素は次の各部にまとめられる。

(1) レーザ発振器部

(2) 光学系部

(3) $X-Y$ ステージ部

(4) システム制御部

以下に, SL 452 Cレーザマスクリペアの構成各部に ついて詳細に述べる。

\section{2 レーザ発振器部}

マスクのよらにガラス基板上の薄膜を加工する場合 には尖頭出力の高いレーザ光を極力短時間に照射して 加工を完了させなければならない、これは，金属のよ らに熱伝導度が高く，からその下にある基板より溶融 温度が高い物質にレーザ照射をする場合に，特に重要 なことである，金属薄膜にレーザを照射すると，吸収 による温度上昇が起こり金属が溶融状態となり，更に 高温となって蒸発する。金属薄膜の除去加工はこのよ うなプロセスを経て行われる。このとき，レーザの照 射時間が長いと周辺への熱拡散が生じ，このため，照 射部外の周辺部まで加工されやすくなり，加工精度が 低下寸ることになる。また，溶融した金属が長くガラ ス基板上に滞留すると，この溶融金属の熱によりガラ スが溶け基板に傷がつくことになる。

このような熱影響を極力少なくするためのレーザと して, 尖頭出力が高く発振時間の短い, パス励起 $\mathrm{Nd}$ ：YAGレーザのQスイッチパルスが適しており， 


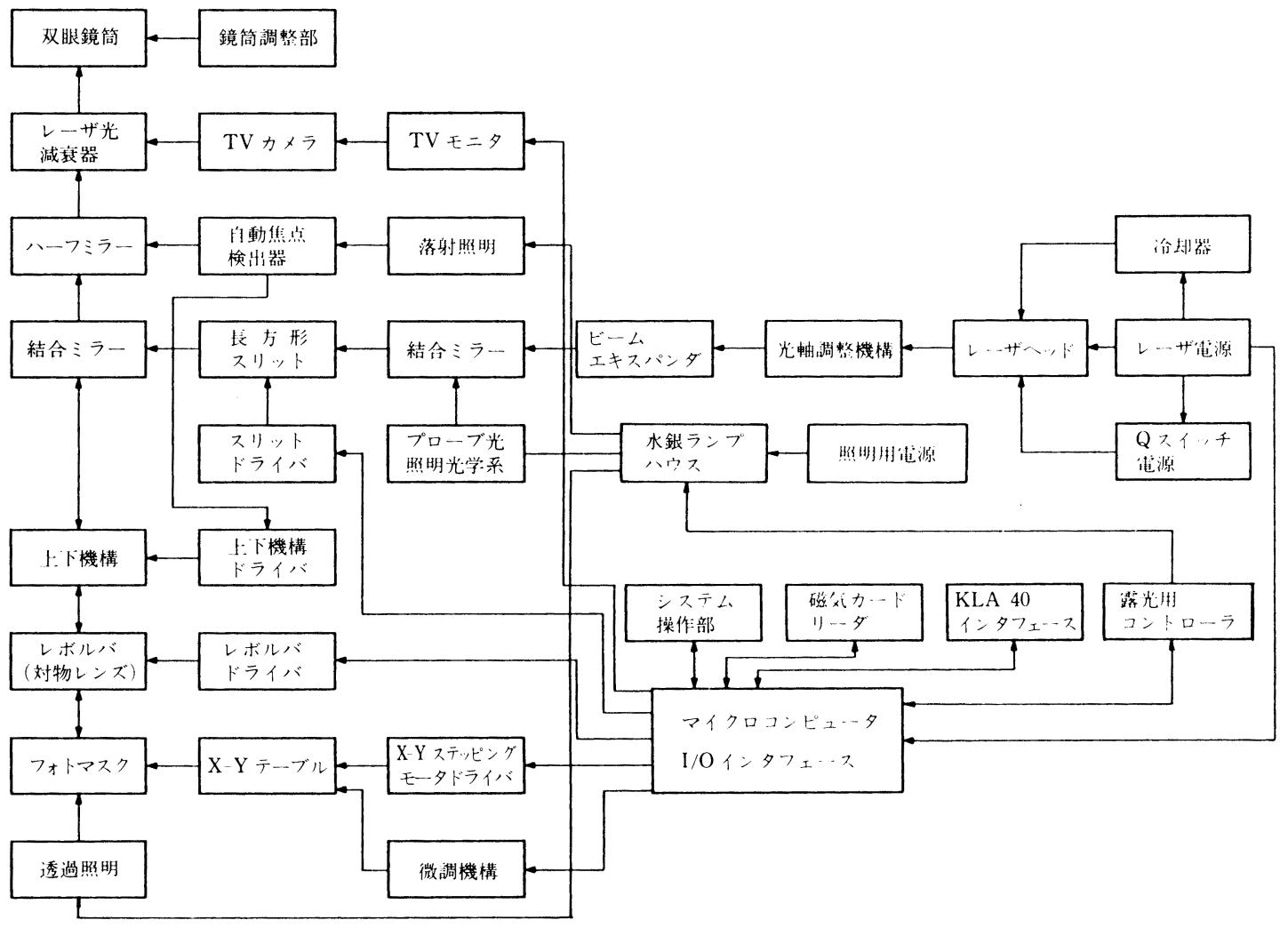

図 5 SL 452 C レーザマスクリペアブロック図

SL 452 Cレーザマスクリペアでは，このレーザの第二 高調波光である $0.53 \mu \mathrm{m}$ 光を採用している.

この装置に用いられているレーザの出力は約 0.7 $\mathrm{mJ}$, 発振パルス幅は $10 \mathrm{~ns}$ 以下で, $\mathrm{TEM}_{00}$ モードに制 御されている。

\section{3 光 学 系 部}

マスク修正の原理の節で述べたように，修正加工は マスク上にレーザ光によるスリット像を結像させて行 われる。すなわち、エネルギーを一点に集光して行ら 他のレーザ加工と異なり，結像加工を行らところに特 徵がある。これは, カメラで写真を撮影するように, ピントが合った状態で加工すれば，一様でシャープな 加工結果が得られる.

SL 452 Cレーザマスクリペアには, シャープなサブ ミクロン加工を行らため種々の配慮がなされている. この光学系は, 約 1000 倍といら高倍率で観察しなが ら修正作業を行らため, 操作部をすべても一タドライ ブとし，更に，焦点合わせを容易にできるよう自動焦 点機構を備えている.

この光学系では, レーザ発振器から出射したレーザ ビームは, 光軸調整された後ビームエキスパンダー゙拡 大され，パイロット光と同軸に調整される.この二つ
の重なったビームは，モータドライブされた可変長方 形スリットによりビームの一部のみが通過し, 対物レ ンズに入射する。このスリットを通過したビームは， その中央部の強度と周辺部の強度の比が 1 に近い程良 質の加工が央現できる。したがって，加工の質を重視 すれば， 1 種類の対物レンズによる加工範曲にも制限 がつく.SL 452 Cレーザマスクリペアでは, 加工する 大きさはサブミクロンから最大 25 ミクロン角までで, 加工には作動距離の長い50 倍の対物レンズが用いら れる。このときのパターンへの焦点合わせにはレーザ ダイオードを用いた自動焦点機構を用いることがで き，レーザの最適加亡点にピント合わせができる、ピ ント合わせはマニュアルでも行らことができ，高低 2 速のモータドライブによって対物レンズを駆動でき る。，矢陷部を見つけやすくするため，低倍率の 対物レンズで観察するときにはレボルバをモータで回 転させ対物レンズを交換することができる。このとき， 誤ってレーザ発射操作を行ってもレーザ光が照射され ないよう禁止回路が働いている.

レーザ照射する範囲を明示する長方形スリットの形 状は，顕微鏡視野内ではだいだい色で示され，顕微鏡 あるいはTVモニタにより調整することができる。 


\section{$3.4 \mathrm{X}$-Y ステージ部}

$\mathrm{X}-\mathrm{Y}$ ステージ部は, 除振・吸振効果の優れた新素材 を利用した定盤機構上に，XYスライド部，駆動部微 調機構，載物台等を配置して構成されている。

$\mathrm{X}-\mathrm{Y}$ ステージの有効駆動範囲は $200 \times 200 \mathrm{~mm}$ であ ク，8”までのマスクに対応できる。駆動部は， $X, Y$ 直交して配置され，それぞれステッピングモータ (0.036\%パル)，ボールスクリュー/ナット（リード長 $5 \mathrm{~mm}$ ) 等から成っている。このX-Y ステージの位置 分解能は $0.5 \mu \mathrm{m}$, 位置精度は土7 $\mu \mathrm{m}$, 最高移動速度 は $14 \mathrm{~mm} / \mathrm{s}$ となっている。更に, 駆動部にはピェゾ 素子を用いた微調機構が組み込まれており， $\pm 15 \mu \mathrm{m}$ の範囲で X-Y ステージを微調移動させることができ る.

\section{5 システム制御部}

SL 452 Cレーザマスクリペアの制御部は，マルチバ スコンソール，ステッピングモータドライバ，システ 么電源等から構成されている。

この装置はりペアとチェックの二つの機能をもって 㧍りスイッチにより選択する。チェックモード時には レーザ発振は禁止され, 久陷位置のデータをストアし 磁気カードに記録することができる。このチェック機 能は主として入力データの確認あるいは欠陷の選別作 業時に用いられる。

リペアモードには，レーザと露光の二つの機能があ り，いずれの場合にも修正と同時に修正位置データの ストア拉よび出力ができる。

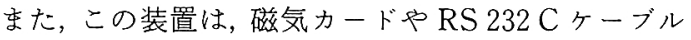
コネクタあるいはフロッピーディスクを介して外部機 器との接続を可能として括り, 修正作業の能率化と品 質管理データの収集を図っている。

これらの動作をコントロールしているCPU は Z 80 で，マルチバス方式を採用している。

\section{6 安全対策}

レーザ光は微細な加工に威力を発揮する反面, 取扱 いを誤ると人に傷害を与えるため危険な光でもある。

特に，この装置のように，顕微鏡観察をしながらレ一， ザ加工をする場合には，作業者の眼の安全確保が不可 欠である。

この装置に使用されているレーザ光は, $\mathrm{Nd} ： \mathrm{YAG}$ レーザの基本波の $1.06 \mu \mathrm{m}$ 光と, その第二高調波で修 正加工に使用している. $0.53 \mu \mathrm{m}$ 光，および自動焦点機 構用光源として使用されているレ一ザダイオードの $0.78 \mu \mathrm{m}$ 光の 3 種類である.

この装置では，米国の安全法規である $\mathrm{CDRH}$ (旧 BRH) 規格にのっとり安全対策を施している，特に観
表 1 SL 452 C レーザマスクリペア（NEC 製）の性能

\begin{tabular}{|c|c|c|}
\hline \multirow{2}{*}{\multicolumn{2}{|c|}{$\frac{\text { 項 }}{\text { 加工分解能 }}$}} & \multirow{2}{*}{ 替格または性能 } \\
\hline & & \\
\hline $\begin{array}{l}\text { レーザ } \\
\text { 装置 }\end{array}$ & $\begin{array}{l}\text { 方式 } \\
\text { 波 長 } \\
\text { モード } \\
\text { パス ス幅 }\end{array}$ & $\begin{array}{l}\text { パルス励起 } \mathrm{Q} \text { スイッチ } \mathrm{Nd}: \mathrm{YAG} \\
\text { レーザの第二高調波 } \\
0.53 \mu \mathrm{m} \\
\mathrm{TEM}_{00} \\
10 \mathrm{~ns} \text { 以下 }\end{array}$ \\
\hline 光学系 & $\begin{array}{l}\text { 倍 率 } \\
\text { スリット幅 } \\
\text { 照明方式 }\end{array}$ & $\begin{array}{l}\text { 約 } 150 \times, 250 \times, 500 \times, 1000 \times \\
<1 \sim 25 \mu \mathrm{m} \\
\text { 透過および落射型 }\end{array}$ \\
\hline $\begin{array}{l}X-Y \\
\text { ステーシ }\end{array}$ & $\begin{array}{l}\text { 分解能 } \\
\text { 精 度 } \\
\text { 移動範团 }\end{array}$ & $\begin{array}{l}0.5 \mu \mathrm{m} \\
\pm 7 \mu \mathrm{m} \\
200 \times 200 \mathrm{~mm}\end{array}$ \\
\hline \multicolumn{2}{|c|}{ データ入出力方式 } & $\begin{array}{l}\text { 磁気カード } \\
\text { RS } 232 \mathrm{C} \text { ケブル } \\
\text { フロッピーディスク }\end{array}$ \\
\hline
\end{tabular}

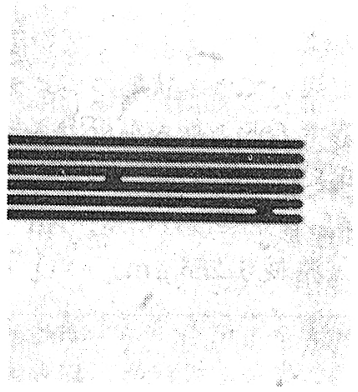

(a) 修正前

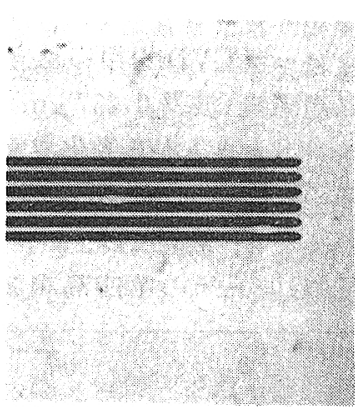

(b) 修正後
察光学系には，吸収フィルタと選択反射鏡の組合せに よりレーザ光の減衰機構を設け，接眼部より出射され るレーザ光の強度を $0.1 \mu \mathrm{J}$ 末満に抑克安全を確保し ている。

\section{7 性 能}

表 1 にSL 452 Cレーザマスクリペアの性能を示す。 またこの装置では, $0.7 \mu \mathrm{m}$ 加工が可能で, 超 LSI 用マ スクに用いられる $1 \mu \mathrm{m}$ 幅のパターンに発生する欠陥 の修正に利用されている。SL 452 Cによる加工例を図 6 に示寸。図 6(a) は修正前の写真で, 黒部 $(1.3 \mu \mathrm{m})$ と白部 $(0.7 \mu \mathrm{m})$ の間にある 2 か所のブリッジを加工 したのが図 6 (b) の写真である。

\section{4. 今後の修正技術の動向}

\section{1 欠損欠陷の修正}

上述の修正装置はレーザを用いた残留欠陥を対象と したものである。しかし，もら一つの欠損欠陥の修正 も同程度に重要であり対策が急がれている。これは， 
無欠宿レチクルを必要とするステッパ露光が超 LSI 転写方式の主流となって以来特に顕著である。そのた め，現在のところはリフフォフと呼ばれる従来方式に より欠損欠陷修正を行っている。この方式は，マスク にフォトレジストを叙布し欠陷部のみをスポット露光 し現像して空をあけた後クロムをスパッタして欠損部 を充てんし，その後フォトレジストを剥離する。この 方法はレーザによる修正技術が開発される以前から残 留，欠損両欠陷に対して行われていた修正方法である が，マスクを製造するのとほぼ同じ工程を通す必要が あるため, 修正コストと時間が欠点である。そのため, 残留欠陥に対するレーザ修正のように，より短時間に 確実に修正する方法の実現が待たれている。

\section{2 新しい修正技術}

このような要求に対して，レーザ CVD あるいは集 束イオンビームを用いた新しい修正技術が開発され実 用化が始まっている。

レーザ CVDを用いた方法は，アルゴンレーザの第 二高調波（波長 $0.257 \mu \mathrm{m}$ ) を用いてガス状態のジメチ ルカドミウムから光化学反応でカドミウムを析出させ るのに成功して以来，実用化に向けての開発が進めら れている. 最近では, アルゴンレーザ以外にも, $\mathrm{Nd}$ ： $\mathrm{YAG} レ$ ーザの第四高調波（波長 $0.266 \mu \mathrm{m}$ ）の $\mathrm{Q}$ ス
イッチパルスを用いた修正方法も開発されている。

一方の集束イオンビームを用いた方法は機械的な傷 を基板はにつけ奏質的に光の透過を遮断しようとする ものである。集束イオンビームを久損欠陷部に照射す るとガラス基板にプリズム状の傷がつき，露光時には そのプリズム状の傷により光を乱反射しウェ八に光が とどかないようにする。その結果，マスクの黑部と同 じ効果を得ることが可能であるといわれている。

今後のマスク修正は，このような新しい修正技術と 従来からのレーザ修正技術が組み合わされた形の複合 修正技術として発展することが望まれている。

\section{文献}

1）中四富紘：マスク㛟枯装㯰，電子材料别冊（1983） 188 ,

2）辰し龍间：ホトマスク修止用加1: 技術, 電子材料, 3 (1978) 49.

3) D. J. Ehrlich, R. M. Osgood, Jr., D. J. Silversmith and T F. Deutsch : One-step Repair of Transparent Defects in Hard-surface Photolithographic Masks via Laser Photodeposition, IEEE, Electron Device Letters. EDL. $1,6,(1980) 101$.

4) Y. Morishige, H. Yokoyama, S. kishida, K. Washio, H. Kinoshita, S. Nakamura and R. Tatsumi: Practical Photomask Pinhole Defect Repair Using Micrometer Scale Pattern Cr CVD with $\mathrm{kHz}$ Repetition UV Light Pulses, CLEO '85, FK 3, Technical Digest, (1985) 286.

\section{創造科学推進事業「ナノ機構」}

新技術開発事業団は, 創造科学推進事業の一つとして, 今年度新たに「吉田ナノ機構プロジェクト」を発足させ た.

創造科学推進事業は, 産・官・学および海外の優秀な 研究者を一定期間（約 5 年間）結集し，新しい科学技術 の芽を発掘するため, 創造性に富んだ探索的研究を遂行 しょらとするものである。

本プロジェクトは, 日本光学吉田庄一郎氏を総括責任 者とし，ナノメータ領域における物質の物理的作用之機 械的性質に着目し，その解析を行うとともに，新しい計 測・加工法の研究を通じ，その機械・機構の要素技術を 探究することを目的としている。

吉田氏の構想によれば，ナノ機構プロジェクトは，基 本解析, 計測・制御, 加工の 3 グループ編成により推進 される.

基本解析グループは, ナノメータ領域に抢ける物理的 作用之機械的性質の基本特性を解析し，温度，振動等外 部要因の基本特性への影響の解析を行う。さらに物理的 作用と機械的性質を変化させる方法の調査・分析を行い， 精密工学技術への適応性を探る。

計測・制御グループは，ナノメータ単位の三次元（形
状）計測の追求を行う。あわせて，計測情報に基づきナ ノメータオーダの精度で計測対象物を位置決め制御でき る手法を探索する。また，位置決め制御に必要な位置検 出機構, 送り機構, 動力伀澾機構等の要素技術を追求す る.

加工グループは，加 Iの基本となる切削，研磨等の除 去加了，薄膜形成等の付加加 I.についてその手法之要素 技術を検討し，ナノメ一夕領域に抢忛る新しい加工法を 探索する。ささらに，それらの手法を駆使して，X 線光学 素子等の作製を試みる。

吉田氏は、このような研究が，半導体，バイオデノ ロジ一を始め，厸し、分野の基盤技術の確立に笴与するば かりでなく，ナノ学ともいらべき新しい份野を切りひ らく基礎になることを期待している。

な招，本ブロジェクトは現在研究員の人選中であり， 本件に関する閵合せ先は下記の通りである。

新技術開発事業㐜・吉时ナノ機構プロジェクト事務所 技術参事・飭场 清

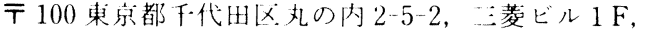
電話 03-216 6731

(原间達男) 